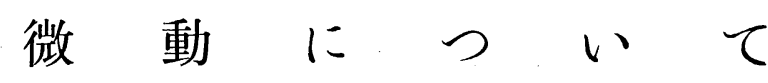

東京大学理学部地球物理学教室 赤松敬

(昭和 31 年 7 月 10 日受理)

\title{
On Microtremors
}

\author{
Kei Акамatu \\ Geophysical Institute, Faculty of Science, Tokyo University
}

(Received July 10, 1956)

In the observations of microtremors and explosion seismics ground noises cause difficulties in picking out the initial movements in seismograms. In order to examine the above problem and determine the characteristic frequency of microtremors of a given locality, it is necessary to investigate these microtremors.

This paper discusses microtremors with frequencies between $20 \mathrm{c} / \mathrm{s}$ and $1 \mathrm{c} / \mathrm{s}$ which were observed at Hongo in Tokyo and Mt. Tukuba. Equipments used were horizontal seismometers of moving coil type with a frequency of $1 \mathrm{c} / \mathrm{s}$, vertical seismometers with frequencies of $3 \mathrm{c} / \mathrm{s}$ and $10 \mathrm{c} / \mathrm{s}$, and two amplifiers one with a band of amplification between $1 \sim 30 \mathrm{c} / \mathrm{s}$ and the other with a band between $30 \sim 100 \mathrm{c} / \mathrm{s}$. Tripartite observations were conducted and parallel observations were made with different frequency seismometers for comparison. The data were analyzed by the methods of autocorrelation and crosscorrelation.

The results of the observations and analyses are:

1. At Hongo for tremors of $7 \mathrm{c} / \mathrm{s}$ to $10 \mathrm{c} / \mathrm{s}$ the daily variation of amplitudes from day to night showed a ratio of $17: 1$. At Tukuba for the frequency of $20 \mathrm{c} / \mathrm{s}$ the ratio of amplitudes in the day time to those in the night was $2: 1$.

2. At Hongo upon observation of tremors with seismometers with frequency responses of $1 \mathrm{c} / \mathrm{s}$, and $3 \mathrm{c} / \mathrm{s}$ and $10 \mathrm{c} / \mathrm{s}$ after calculation of the power spectra, tremors with frequencies of $2 \sim 5 \mathrm{c} / \mathrm{s}, 7 \sim 9 \mathrm{c} / \mathrm{s}$ and $10 \mathrm{c} / \mathrm{s}$ were found; at Tukuba using seismomoter with $3 \mathrm{c} / \mathrm{s}$ response tremors with $20 \mathrm{c} / \mathrm{s}$ frequency were found.

3. By using the data from tripartite observation time difference of wave arrivals between two points was obtained by the method of crosscorrelation to determine the direction of wave propagation and the phase velocity.

4. Space correlation between two points decreased more rapidly for shorter period waves than for longer ones.

\section{§1.まえがき}

この研究の対象となる微動はその周期が数秒以下の雑微動とか常時微動とかいわれているも のである. 微小地震或は爆破地震動を観測する際に, 土地の noise の最も少い場所を求めても まだ多小土地の noise があり，地震波の初動と区別するのに困難な事も起る. この様な場合 に灶適当な filtering を行つて徽動の影響を小さくする事も必要となる. 又は group setting の方法を用いて singal を大きくする事も望ましい. 
常時微動の観測についてすでにいくつかの論文があり，地震波が通過する際にとの土地の固 有振動周期が卓越する様に，微動によつてもその場合と同様の周期が卓越するという事，すな わち微動を観測する事によつて土地の地盤のいわゆる“固有周期”がわかるといわれている1),2). 又常時微動は主として表面波より成るという考方方もある3). 地盤の固有振動は地層による重 複反射の結果であると考光られているので()，上述の二通りの考光方は矛盾する様にるみえる が微動にも実体波的な部分と表面波的な部分が重畳していると考皃る事もさしつかえない.

微動の原因となるものは土地により又場合により異なり，微動の波としての具体的ななりた ちも様々であろう，微動の 現 象 論的な性質を理解する事は以上の問題に対して重要な事であ り，そして出来れば更に立入つていわゆる常時微動がぞの様な境界をもつ媒質中でどの様な 波からなりたつているかを知る事は，上述の諸間題に対して根本的な解決を与年る事になる. この論文では本郷と筑波山で㢄夜の微動を観測し，得られた記録に対して解析を行つた結果を 述べる.

\section{§ 2. 観測器械及び観測の方法}

観測に用いた器械は地震計としては固有周波数 $3 \mathrm{c} / \mathrm{s}$ の電磁式上下動地震計 3 台, $10 \mathrm{c} / \mathrm{s}$ 上下 動 2 台, 及び $1 \mathrm{c} / \mathrm{s}$ 電磁式水平動地震計 3 台, 堌巾器としては爆破地震動観測に用いられる带 域 $1 \mathrm{c} / \mathrm{s} \sim 30 \mathrm{c} / \mathrm{s}$ のもの及び微小地震観測用增巾器である.この増巾器は帯域がより短周期の方 にあり $10 \mathrm{c} / \mathrm{s}$ 地震計と組合せて用いられる．前者に対しては本郷で観測する時は $R=300 \mathrm{k} \Omega$, $C=2 \mu \mathrm{fd}$. による積分回路を追加して用いている.

観測の方法は上下動 $3 \mathrm{c} / \mathrm{s}, 10 \mathrm{c} / \mathrm{s}$ ，水平動 $1 \mathrm{c} / \mathrm{s}$ の 3 台の地震計を観測室のコンクリート台 に置いて日変化等の 観測を行う． 又 3 台の上下動及び 3 台の水平動で 屋外で 3 点観測を行つ た.この時直角三角形の直角をはさむ 2 辺を順に $1 \mathrm{~m}$ づつひろげて観測した. 筑波山では微 動の振巾について屋夜の観測を行つた.

得られた記録は，1)振巾の日变化，2)各記録の自己相関，3） 2 点の相互相関，4)記録上直接 に波形をよみ取る事，5)振巾の分布，6)筑波山と本郷との記録の比較などを求めて，微動の日 变化，周期，波の現象論的な性質について考察した。

\section{§3. 振巾の日変化}

$3 \mathrm{c} / \mathrm{s}, 10 \mathrm{c} / \mathrm{s}$ 上下動, $1 \mathrm{c} / \mathrm{s}$ 水平動の 3 台の地震計により 1955 年 10 月 13 日 $13 \mathrm{~h}$. から 10 月 14 日 $12 \mathrm{~h}$.にかけて約 1 時間おきに観測を行つた. この日は昼夜共晴で風もなく二三日前から 雨も降らなかつた。観測時間はそれぞれー時間掞きに約二分間である。Fig. 1 に記載してあ る振巾は各記録の振巾の絶対值の平均の值がとつてある. $(1 \mathrm{c} / \mathrm{s}$ 地震計で観測した記録の振巾 は地動の約 10000 倍である.) 一見してわかる事は $3 \mathrm{c} / \mathrm{s}$ 地震計によつて記録される微動の振巾 
の日变化が激しい事である、すなわち前 日の $16 \mathrm{~h} .30 \mathrm{~m}$. の振巾と夜中の $2 \mathrm{~h}$. 振巾 の比は 17:1 である. これに対して $1 \mathrm{c} / \mathrm{s}$ と $10 \mathrm{c} / \mathrm{s}$ の地震計による記録は $4: 1$, $6: 1$ であつて $3 \mathrm{c} / \mathrm{s}$ 程激しい变化は示し ていない. 各々の記録からコレログラム を作つてみると $1 \mathrm{c} / \mathrm{s}$ 水平動地震計では 2〜 $5 \mathrm{c} / \mathrm{s}$ 附近の地動を, $3 \mathrm{c} / \mathrm{s}$ 上下動地 震計では 7〜 $10 \mathrm{c} / \mathrm{s}$, 及び $10 \mathrm{c} / \mathrm{s}$ 地震計 では 8〜 $10 \mathrm{c} / \mathrm{s}$ 及びそれ以上の地動をよ く記録する様である. 友田，安芸が指摘 した様に4) $1 \mathrm{c} / \mathrm{s}$ 以上の微動は交通機関 に関係があるという事は今度の観測にも あらわれている。

以上の様に $1 \mathrm{c} / \mathrm{s}, 3 \mathrm{c} / \mathrm{s}$, 及び $10 \mathrm{c} / \mathrm{s}$ の地震計で観測した結果興味ある日变化 の有様がわからたわ惊であるが， $3 \mathrm{c} / \mathrm{s}$ 地震計による記録のみ 17 倍位の甚しい 日変化を示す事については簡単に説明を

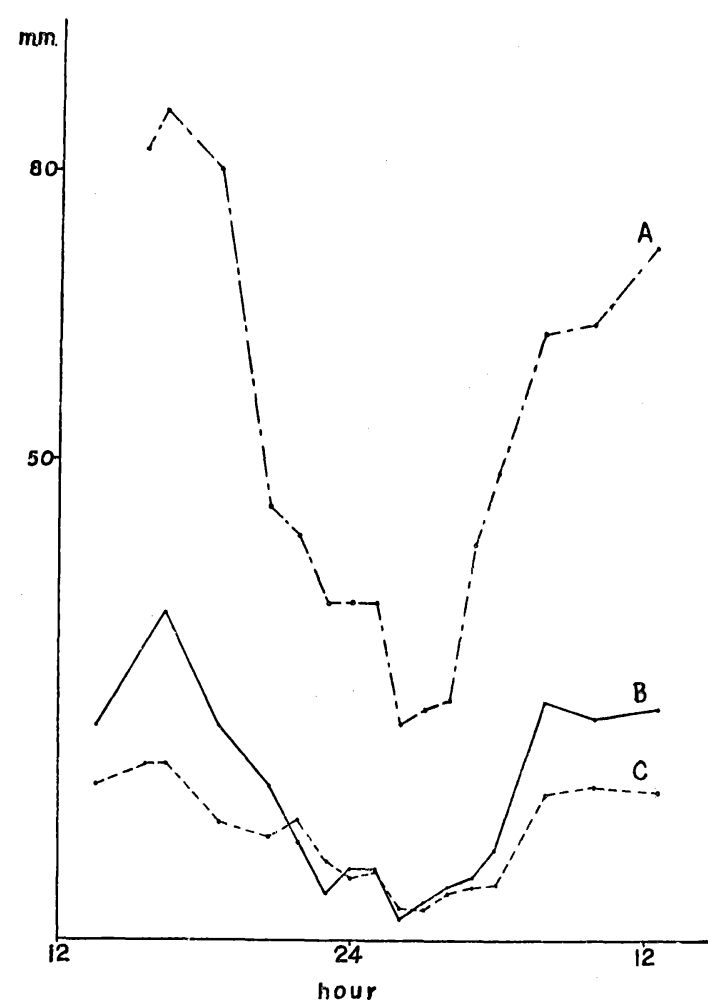

Fig. 1. Daily variation of amplitudes of microtremors.
A $1 \mathrm{c} / \mathrm{s}$ Horizontal seismometer
B $3 \mathrm{c} / \mathrm{s}$ Vertical seismometer
C $10 \mathrm{c} / \mathrm{s}$ Vertical seismometer

\section{B}

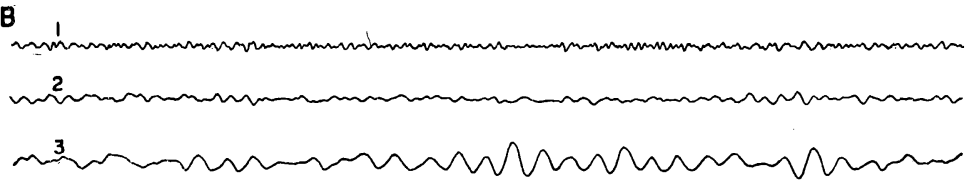

Fig. 2.

A Day (12 h.)

B Night (02 h.)

$110 \mathrm{c} / \mathrm{s}$ Vertical seismometer

$23 \mathrm{c} / \mathrm{s}$ Vertical seismometer

$31 \mathrm{c} / \mathrm{s}$ Horizontal seismometer

(The ratio of sensibility of amplifier in the day time to that in the night was $1: 2$ for $1 \mathrm{c} / \mathrm{s}$ and $10 \mathrm{c} / \mathrm{s}$ seismometers and $1: 5$ for $3 \mathrm{c} / \mathrm{s}$ seismometer) 

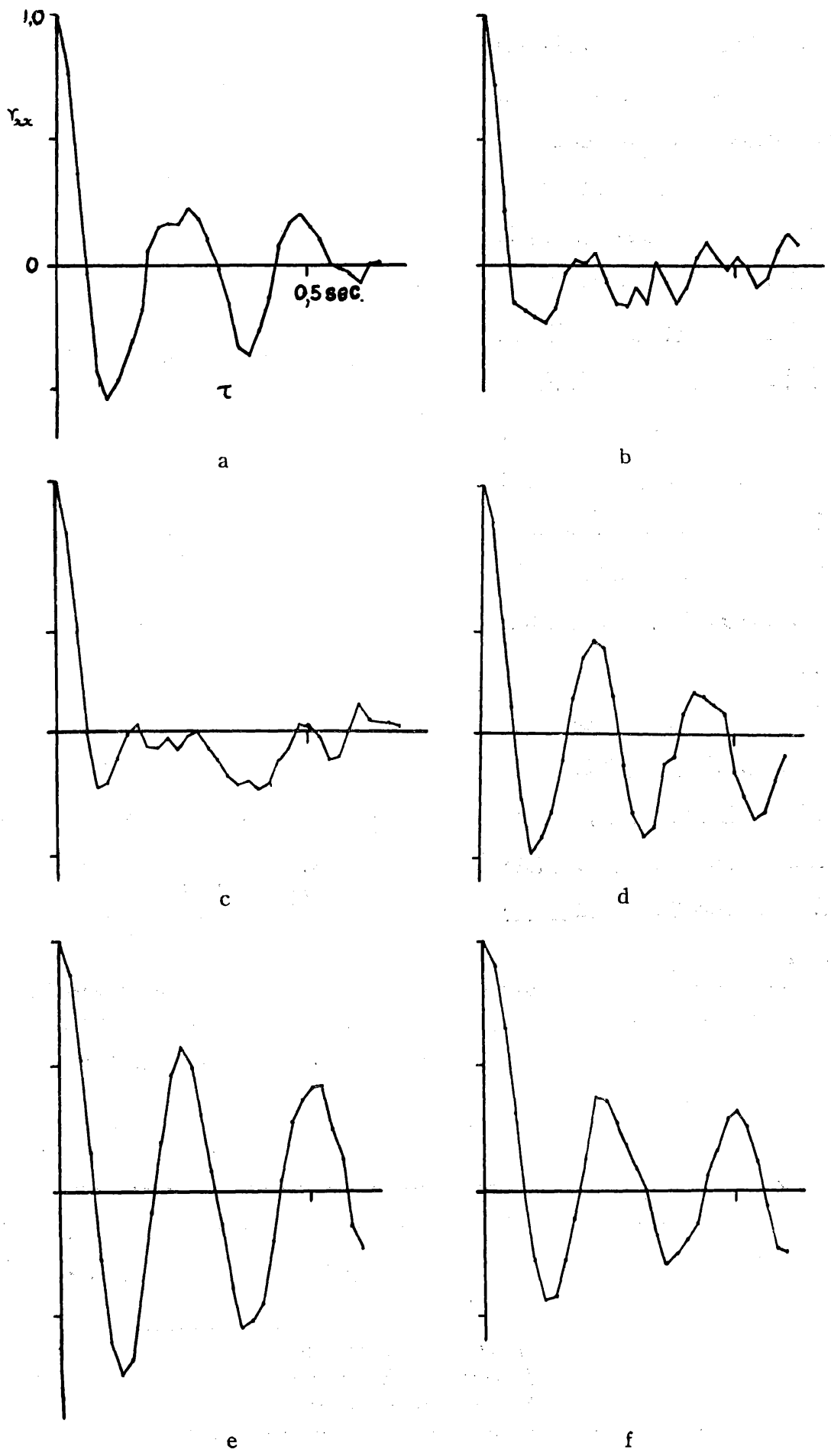

Fig. 3. Correlograms

A $1 \mathrm{c} / \mathrm{s}$ Horizontal seismometer

e, f On a concrete block

f In the night 


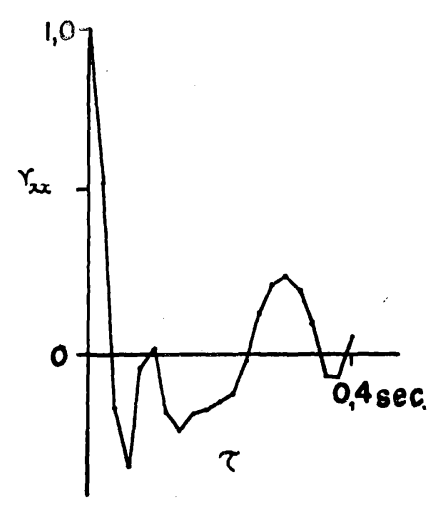

a

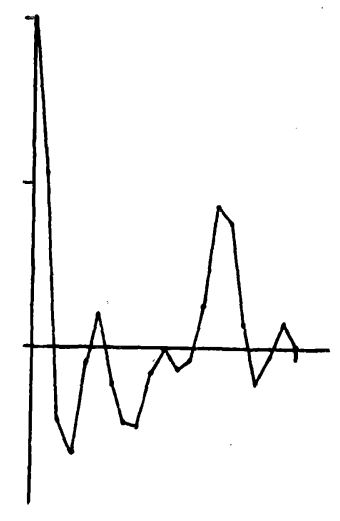

d

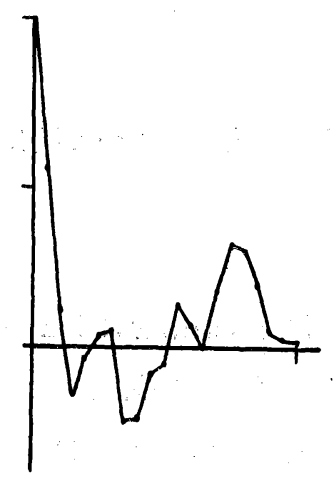

g

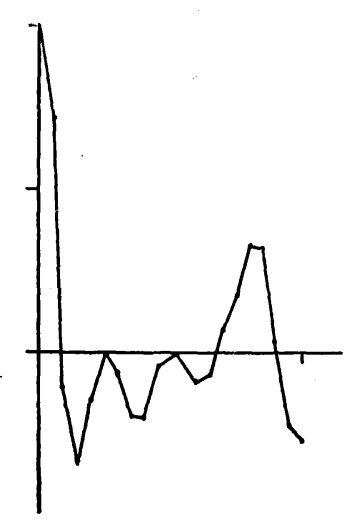

b

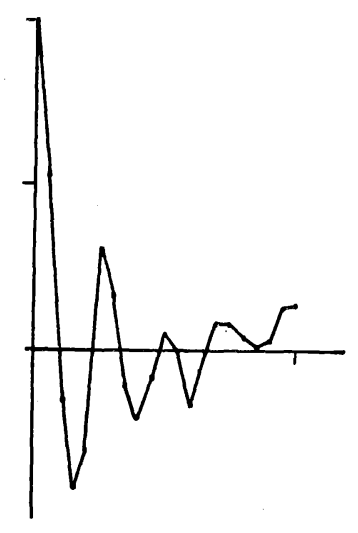

e

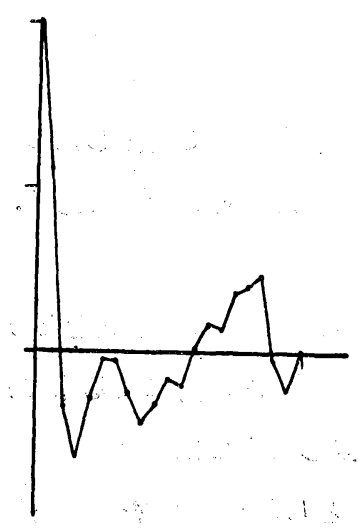

$\mathrm{h}$
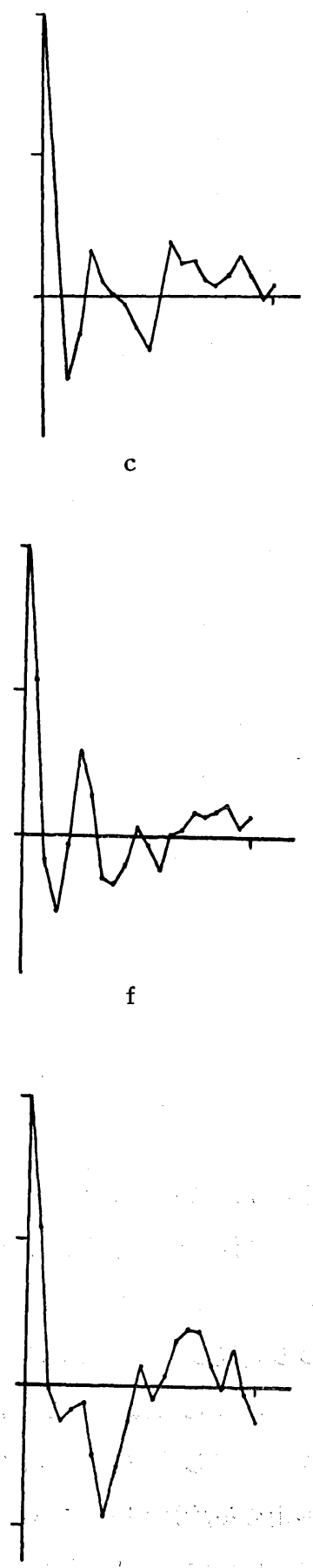

i

Fig. 3. B 3c/s vertical seismometer 


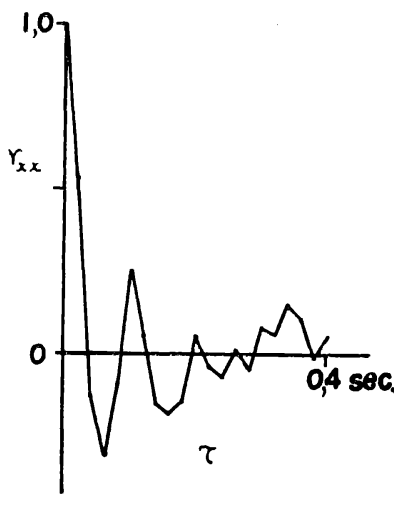

j

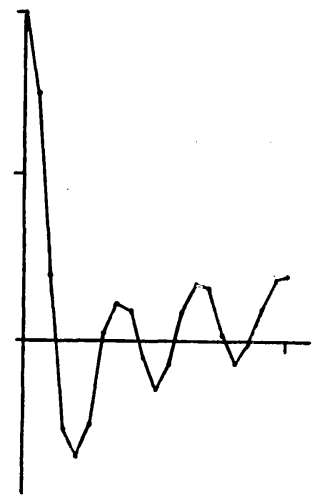

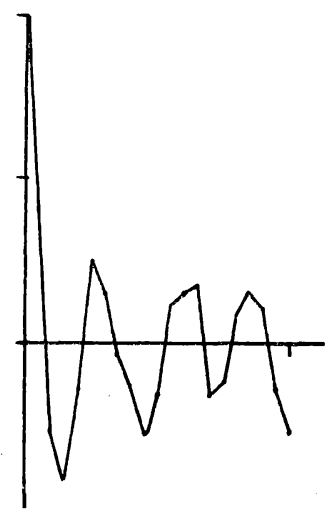

k

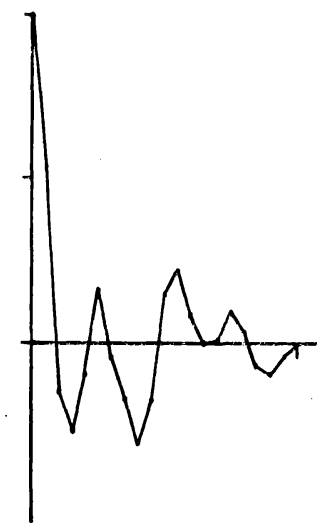

1

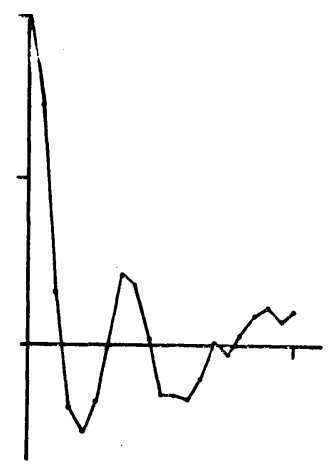

$\mathrm{m}$

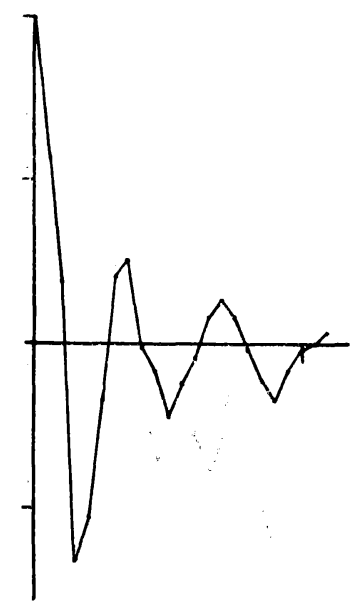

$\mathrm{n}$

Fig. 3. B $3 \mathrm{c} / \mathrm{s}$ Vertical seismometer $\mathrm{m}, \mathrm{n}, \mathrm{o}$ On a concrete block $\mathrm{m}$, o In the night

与えるわけにはいかない，日変化は本郷のみで観測したのであるが，土地によつて昼夜の振巾 の比にどの位変化があるかという事も興味ある問題である.

\section{§ 4. コレログラムによる解析}

一つの記録の series についてある時刻から 6 秒間をとり $1 / 50$ 秒每に振巾をよみとつた．従 つて sample の数は 300 である $(10 \mathrm{c} / \mathrm{s}$ 地震計によるるのは $1 / 100$ 秒每, 4 秒間, sample の 数は 400). 但し $1 \mathrm{c} / \mathrm{s}$ 地震計で記録したものは $1 / 50$ 秒毎 8 秒間, sample の数は 400 であ る. 振巾の積 $f(t) f(t+\tau)$ で $\tau=\kappa \tau_{0}$ とした時, $\tau_{0}$ を $1 / 50$ 秒， $\kappa=1, \ldots \ldots, 20(1 \mathrm{c} / \mathrm{s}$ 地震計の 記録については $\kappa=30$ まで）までととり．振巾は十，一でよみとり友田の方法らで相関係数 を求めてコレログラムを作つた。 これらを Fig. 3. A， B，C に示す. 
「実際に振巾を区間 50 と分けてよ みとつて計算した場合を Fig. $4 \mathrm{~A}$, B に示す. graph によれば, $\kappa=10$ 位までは両者がよく一致して いる. 10以降は合わない所も市が 後に述べる様に短時間自己相関函数 によるスペクトラムをとる時，10以 降は殆ど影響がない，スペクトラム

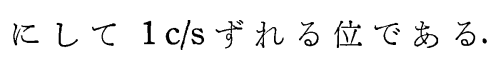
sampleを300 位とれば微動の場合

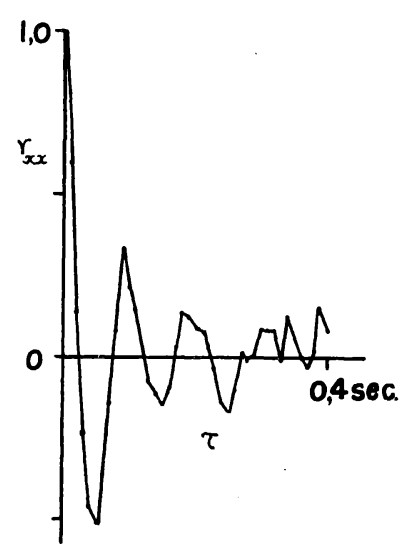

a

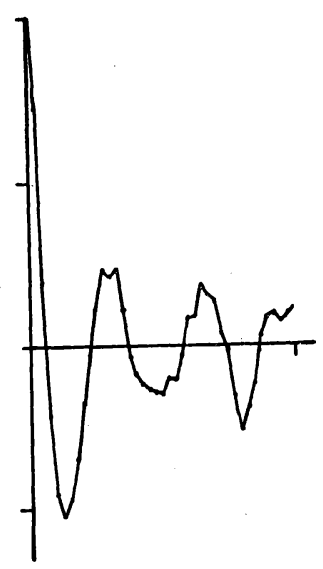

c

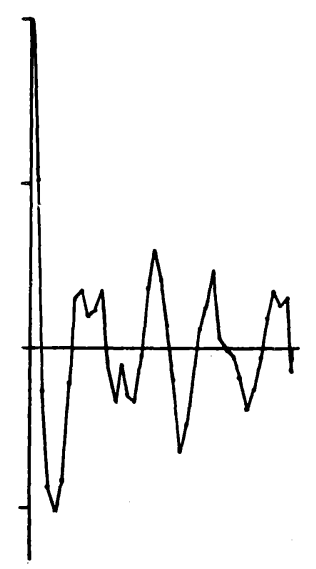

b

には，十，一でも実際に振巾をよみ とる場合と同様にとの性質を論ずる 事が出来るのである.」阝)

結果をみると，記録される周期は 地震計の固有周期によつて異り, 1 $\mathrm{c} / \mathrm{s}$ 及び $3 \mathrm{c} / \mathrm{s}$ 地震計によるるのは sample によつてはつきりした周期 がわからないるのがある. $1 \mathrm{c} / \mathrm{s}$ 地 震計による記録からのコレログラム は大体 $\tau=1 \mathrm{sec}$. で減衰を示してい るが, $3 \mathrm{c} / \mathrm{s}$ 地震計によるものは減衰 を示す事なくコレログラムが振動し

Fig. 3. C $10 \mathrm{c} / \mathrm{s}$ Vertical seismometer c, d On a concrete block d In the night

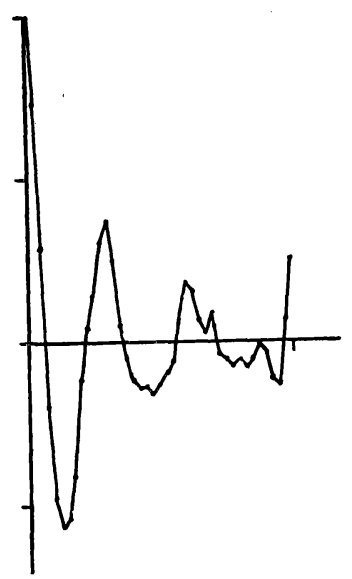

d

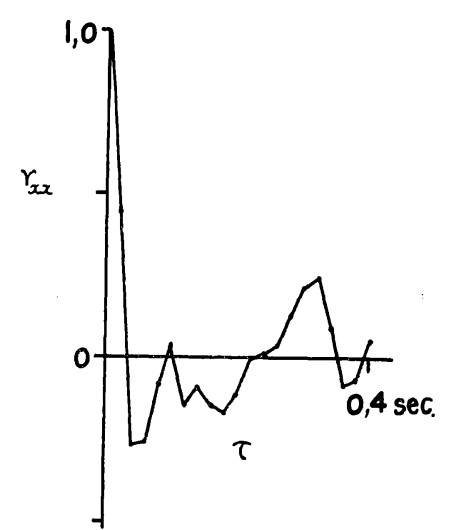

a (cf. Fig. 3 B-a)

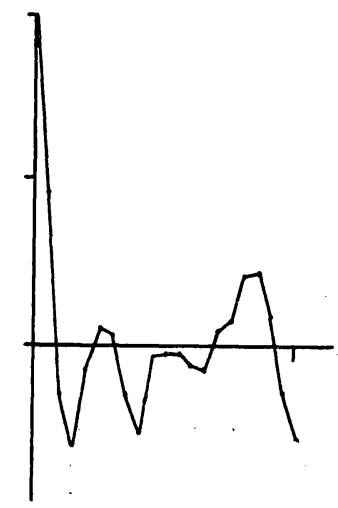

b (cf. Fig. 3 B-b)

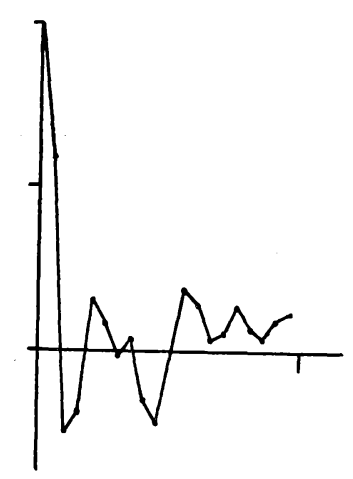

c (cf. Fig. 3 B-c) Fig. 4. A Correlograms deduced by the customary method of calculation. 


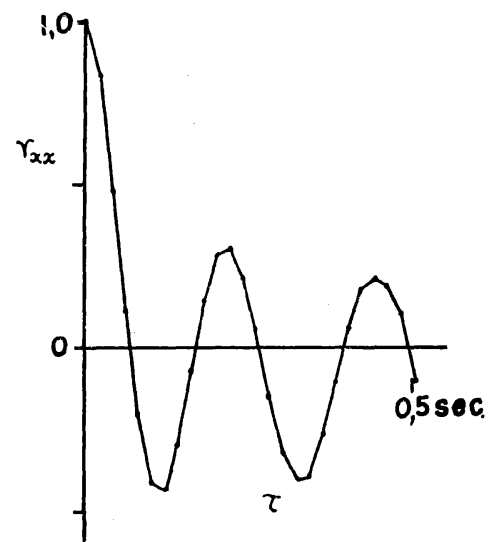

d (cf. Fig. 3 A-d)

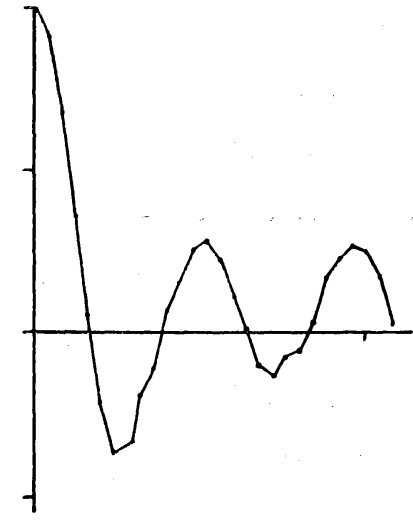

e (cf. Fig. 3 A-f)

Fig. 4. A
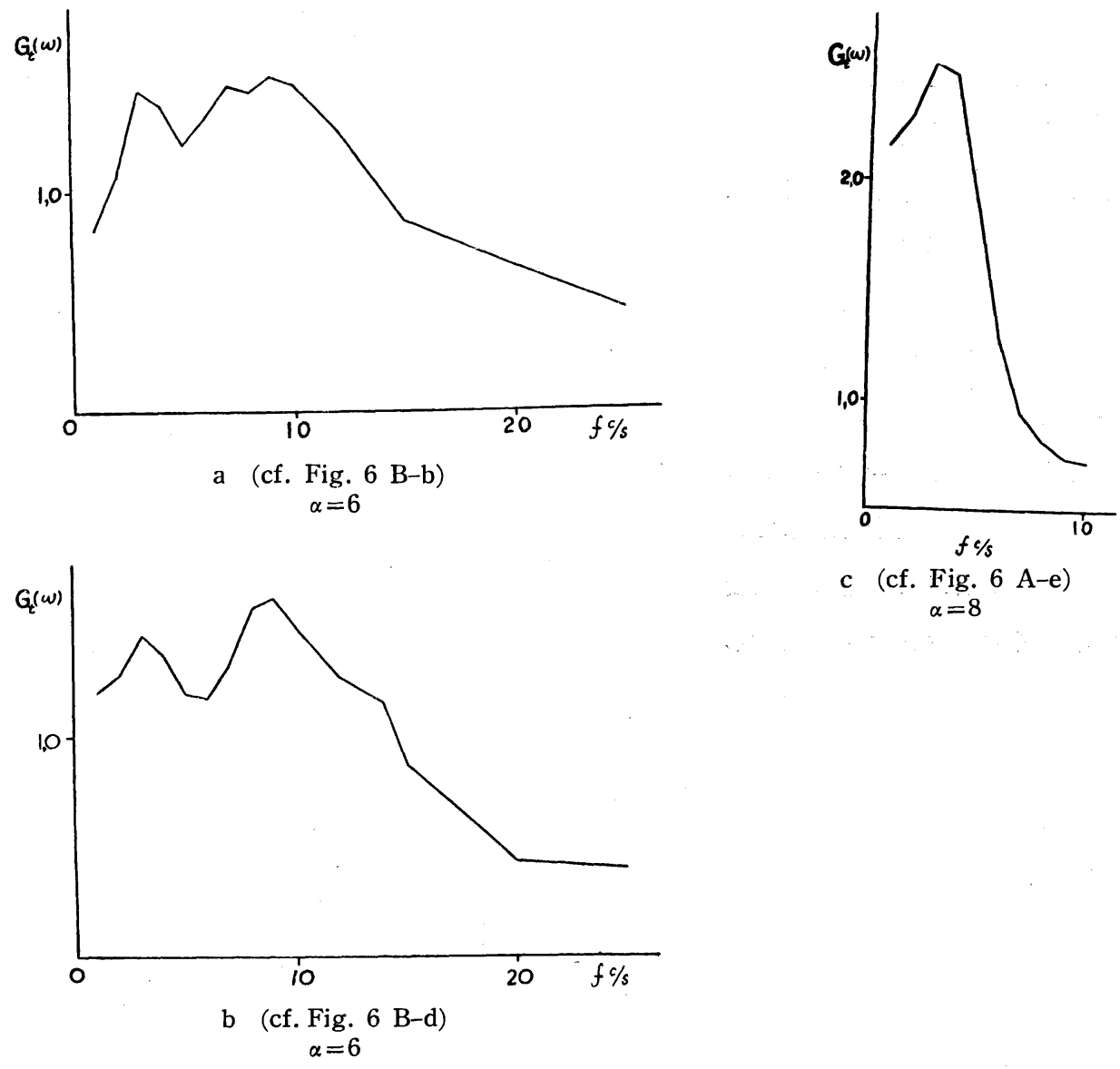

c (cf. Fig. 6 A-e)

Fig. 4. B Spectra a spectrum from Fig. 4 A-a b ", ", Fig. 4 A-c c , , ," $\quad$ Fig. 4 A-e 
ている.コレログラムが減衰を示さない事 sampleによつてコレログラムの様子が異つている という事, つまり約 6 秒（sample 300）の観測では必ずしも定常ではないので, 短時間自己相 関函数を用いてスペクトラムを求める事にした，短時間自己相関函数によるスペクトラムを求 める場合, 問題となるのは $1 / 2 \alpha$ すなわち解析時間であるが, これは相関係数の隇衰の状態 $(\kappa=20$ で約 1/100) と本郷で得られた記録より考えて $\alpha=4 \sim 8$ にえらんだ.

「短時間自己相関函数及び Power spectrum は R. M. Fano 》)よれば次の栐に示される.

$$
\begin{aligned}
\phi_{t}(\tau) & =e^{\alpha|\tau|} / 2 \pi \int_{-\infty}^{\infty} G_{t}(\omega) \cos \omega \tau d \omega \\
G_{t}(\omega) & =\int_{-\infty}^{\infty} e^{-\alpha|\tau|} \phi_{t}(\tau) \cos \omega \tau d \tau
\end{aligned}
$$

短時間自己相関函数によつて power spectrum を求める事は time constant $1 / 2 \alpha$ をるつ た low pass filter あるいは time constant $1 / 2 \alpha$, natural frequency $\omega$ をるつた band pass filterを通す事と同じ結果となる.

例えば Fig. 5 に示す low pass filter の impulse response は

$$
e_{\alpha}(t)=2 \alpha e^{-2 \alpha t} u(t)
$$

ここで $u(t)$; unit step function $\dot{u}(t)=1 t>0$

$$
u(t)=0 \quad t<0
$$

であるから filter の outputは,

$$
\begin{gathered}
\phi_{t}(\tau)=2 \alpha \int_{-\infty}^{t} \phi_{\tau}(x) e^{-2 \alpha(t-x)} d x \\
\phi_{\tau}(t)=f(t) f(t-\tau)
\end{gathered}
$$

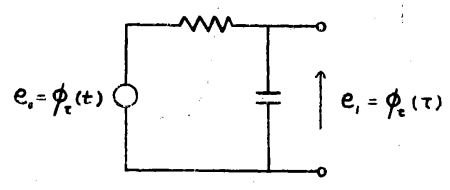

$2 \alpha=\frac{1}{R C}$

Fig. 5.

この $\phi_{t}(\tau)$ が短時間自己相関函数である.

input $f(x)$ と重久の函数 $(2 \alpha)^{1 / 2} e^{-\alpha(t-x)} u(t-x)$ をかけた $x, t$ の函数

$$
F_{\iota}(x)=(2 \alpha)^{1 / 2} f(x) e^{-\alpha(t-x)} u(t-x)
$$

を考え，次に

$$
\psi_{t}(\tau)=\int_{-\infty}^{\infty} F_{t}(x) F_{t}(x-\tau) d x
$$

とすれば

$$
\begin{gathered}
\phi_{t}(\tau)=2 \alpha e^{-\alpha \tau} \int_{-\infty}^{\infty} f(x) f(x-\tau) e^{-2 \alpha(t-x)} u(t-x) u(t-x+\tau) d x \quad \tau>0 \\
\phi_{t}(\tau)=e^{\alpha|\tau|} \phi_{l}(\tau)=2 \alpha \int_{-\infty}^{t} f(x) f(x-\tau) e^{-2 \alpha(t-x)} d x
\end{gathered}
$$

そなつて $\phi_{i}(\tau)$ が単時間自己相関函数である， $\phi_{i}(\tau)$ と power spectrum $G_{t}(\omega)$ との関係は 次の様に示される. 
ここで

$$
\psi_{t}(\tau)=1 / 2 \pi \int_{-\infty}^{\infty} g_{t}(\omega) \overline{g_{t}}(\omega) e^{j \omega \tau} d \omega=1 / 2 \pi \int_{-\infty}^{\infty} G_{t}(\omega) \cos \omega \tau d \omega
$$

$$
\begin{aligned}
g_{t}(\omega) & =\int_{-\infty}^{\infty} F_{t}(x) e^{-j \omega x} d x \\
G_{t}(\omega) & =g_{t}(\omega) \bar{g}_{t}(\omega)=\left|g_{t}(\omega)\right|^{2}
\end{aligned}
$$

$\bar{g}_{t}(\omega) ; g_{t}(\omega)$ の conjugate complex

Fourier 変換によつ $\left.\quad G_{t}(\omega)=\int_{-\infty}^{\infty} \psi_{t}(\tau) \cos \omega \tau d \tau\right\rfloor$

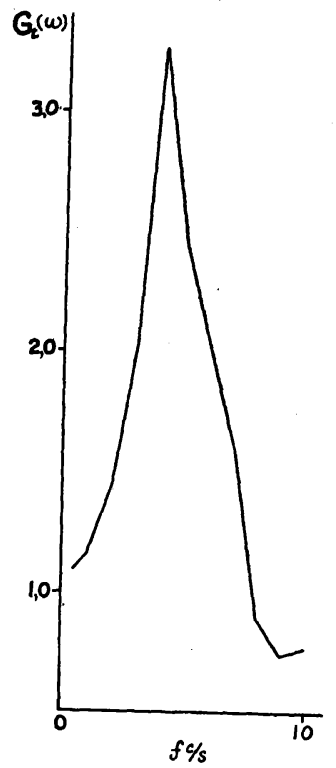

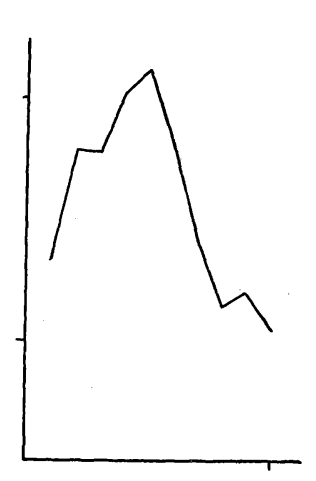

b (Fig. $3 \quad$ A-b) $\quad \alpha=4$

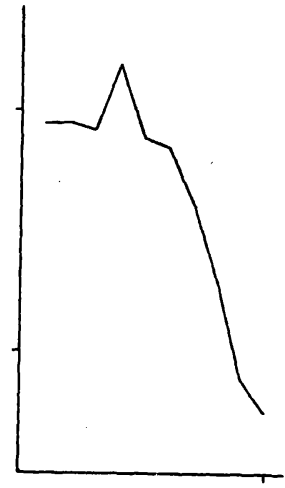

c (Fig. 3 A-c) $\alpha=4$

a (Fig. $3 \quad \mathrm{~A}-\mathrm{a}) \quad a=4$

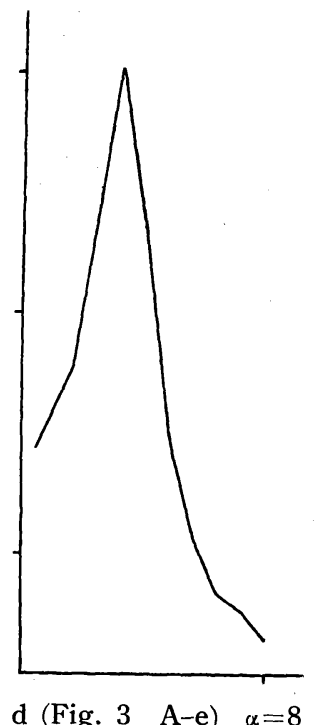

d (Fig. 3 A-e) $\alpha=8$

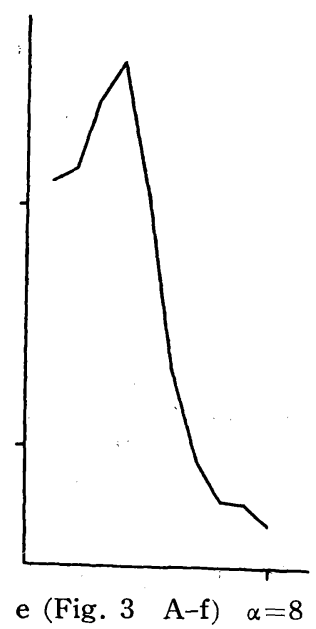

Fig. 6. Spectra A $1 \mathrm{c} / \mathrm{s}$ Horizontal seismometer . 


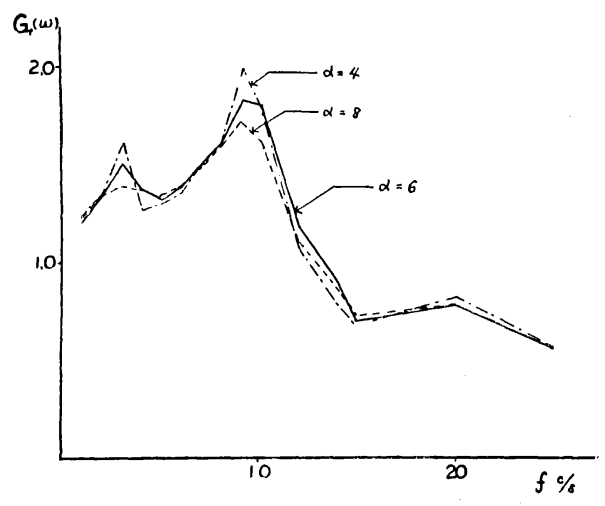

a (Fig. 3 B-j)

$$
\alpha=6
$$

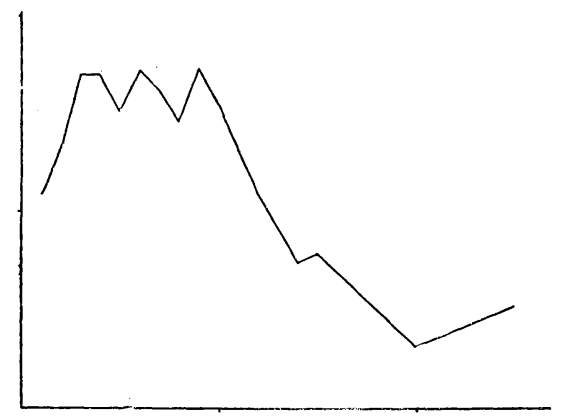

c (Fig. 3 B-b)

$$
\alpha=6
$$

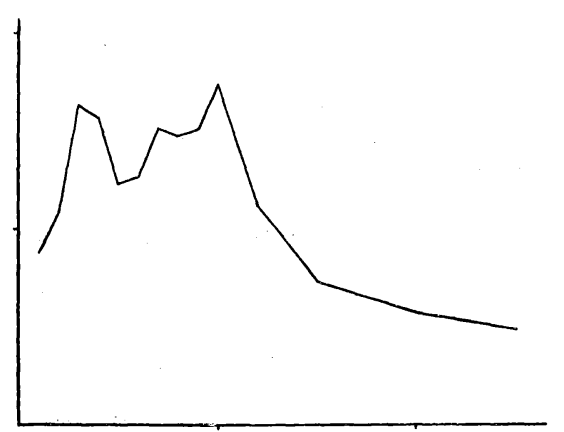

e (Fig. 3 B-d)

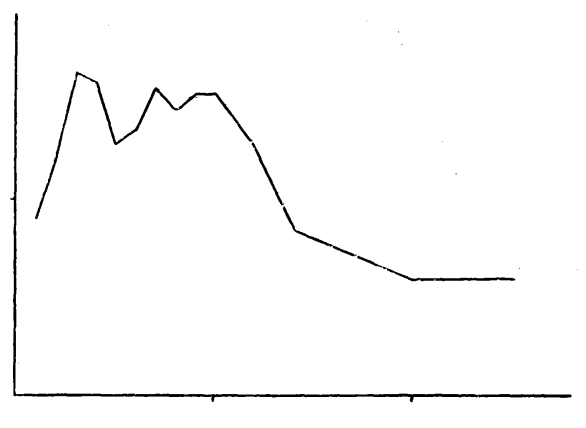

b (Fig. 3 B-a) $\alpha=6$

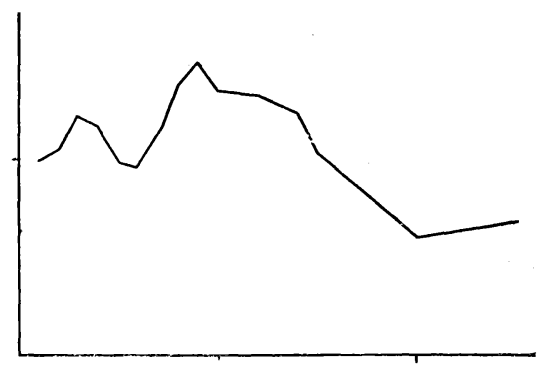

d (Fig. 3 B-c) $\alpha=6$

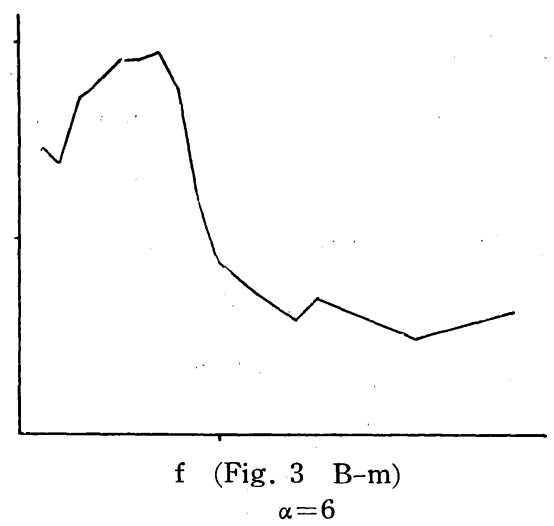

Fig. 6. B $3 \mathrm{c} / \mathrm{s}$ Vertical seismometer. 


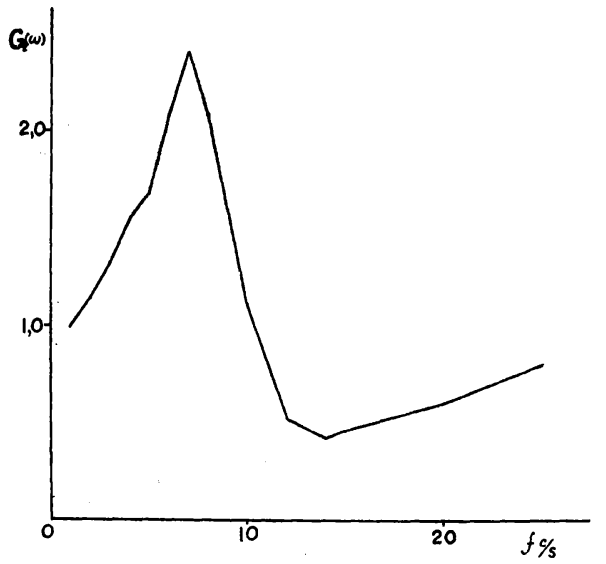

g (Fig. 3 B-n) $\quad \alpha=6$

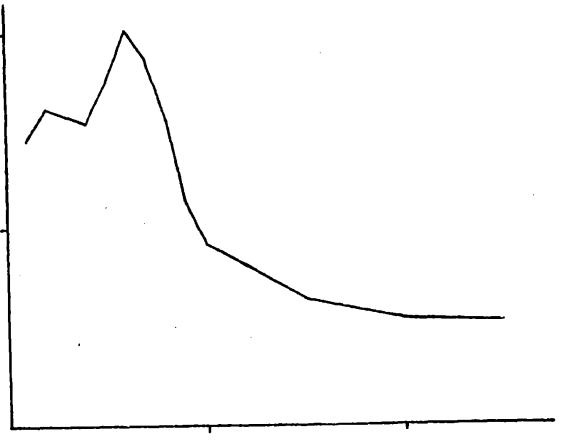

h (Fig. 3 B-o) $\quad \alpha=6$

Fig. 6. B $3 \mathrm{c} / \mathrm{s}$ Vertical seismometer

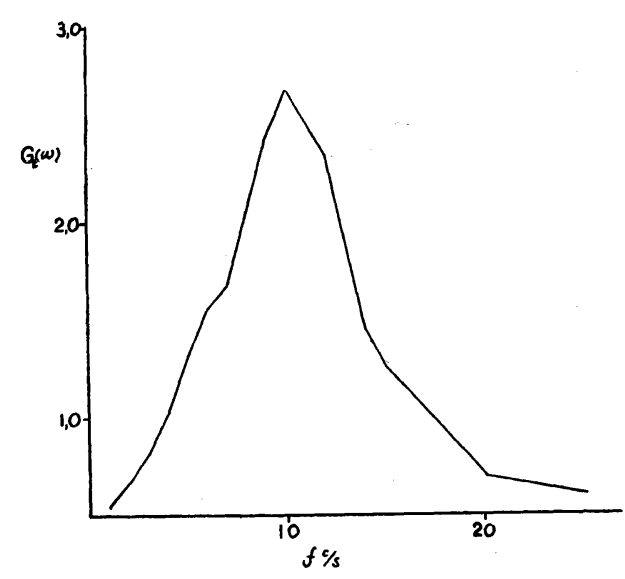

a (Fig. 3 C-a) $\quad \alpha=8$

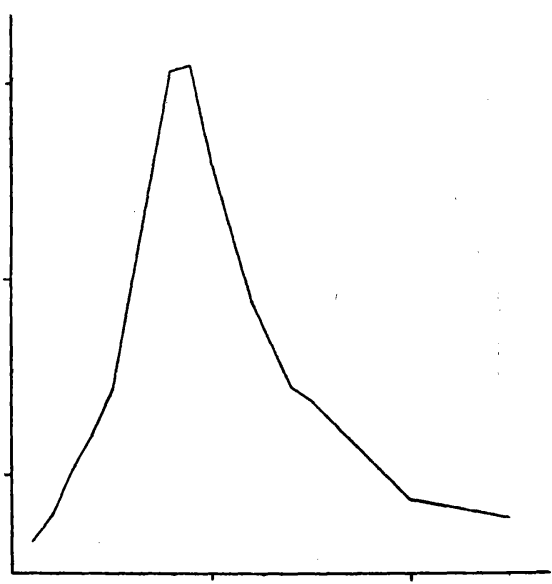

b (Fig. $3 \quad$ C-c) $\quad \alpha=8$

Fig. 6. C $10 \mathrm{c} / \mathrm{s}$ Vertical seismometer

スペクトラムを求めた結果をFig. 6. A, B , C に示す. スペクトラムを見ると室内（コンクリ 一ト台)で観測したものは短周期が少く，スペクトラムの山の数も少い. 屋外(土の上)で観測し たものの方が数種の周波数のものが含まれている事がみとめられる．このことは一秒より短い 程度の地震波を観測する場合にもコンクリート台については十分に注意しなくてはならない事 を示している. graph を見て明らから様に， $1 \mathrm{c} / \mathrm{s}$ 地震計によるるのは 3〜 $4 \mathrm{c} / \mathrm{s} に$ sharp な山 が出ている．これは記録を直接見てもこの周波数の wave train がみられる．地面の上で観測 したものは 1 $5 \mathrm{c} / \mathrm{s}$ の波が多い様である. スペクトラムにも sharpなものと割合に flat なる のがみられる. $3 \mathrm{c} / \mathrm{s}$ 地震計で観測したものは， $3 \mathrm{c} / \mathrm{s}$ と 7 10 c/s が顕著である. 更に細かく みるとある時刻から 6 秒の区間の後すぐ次の 6 秒間のスペクトラムは多小異り，(Fig. 6. B.a， 
c) 又 $8 \mathrm{~m}$ はなれて観測した 2 点の同時のスペクトラムもわずかに異つている. (Fig. 6. B. b,e) $10 \mathrm{c} / \mathrm{s}$ の地震計で観測したものは何れも sharp なスペクトラムがみられ，主な波は $8 \sim 10 \mathrm{c} / \mathrm{s}$ の波である.以上の結果によれば，6秒を一つづきの区間としてとれば刻々にスペクトラムは 変化しているのであつて, 微動の伝播性をあらわす一つの根拠として考觉られるのである. 或 は微動は全く randomなるのの寄集りでなくて規則的な波が含まれていると考えられる. 夜 と㺼の各々のスペクトラムについては著しい差はない㥞である.

\section{§ 5. Tripartite Station による観測}

i) 3 点観測は直角三角形の直角をはさむ二辺の長さを $1 \mathrm{~m}$ 毎 $(1 \mathrm{c} / \mathrm{s}$ の地震計では $2 \mathrm{~m}$ 毎) に辺をのばして観測を行つた．使用 した地震計は $3 \mathrm{c} / \mathrm{s}$ 上下動 3 台, 1 $\mathrm{c} / \mathrm{s}$ 水平動 3 台で場所は本鄉地球物 理学教室前庭である. 又别に $10 \mathrm{c} / \mathrm{s}$ 上下動地震計 2 台で 2 点観测をも行 つた.

3 点観測によつて定常的な振動で あるか否か, 又もし伝播する波であ るならばその進行力向を求める事が 目的の一つである. 先ず 3 点観測に よる記録から 2 点の相互相関係数を 求めて, 2 点の距離每に plot して graphを作つた. ある地盤全体が一 様に振動しているものならばある程 度の距離までへだたつた 2 点の相関 はほડ゙いつでも同じ程度に高いであ ろう。結果は距離がはなれるにした がつて, 多少のふらつきはあるが, 徐々に相関がへつて行くのがみられ る. そのへり方は図に示される様に 周期の短い地震計によるものの方が 急激である.この事については後で 直接記録をみる事によつて更にくわ

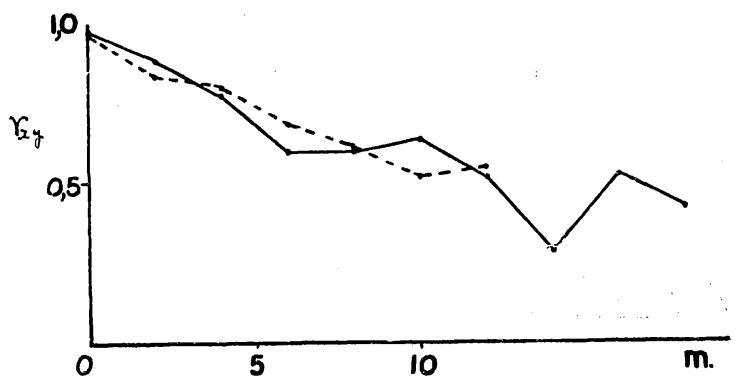

a $1 \mathrm{c} / \mathrm{s}$ Horizontal seismometer

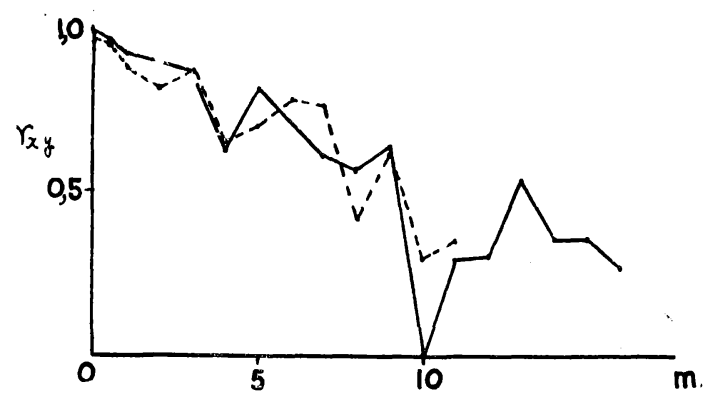

b $3 \mathrm{c} / \mathrm{s}$ Vertical seismometer

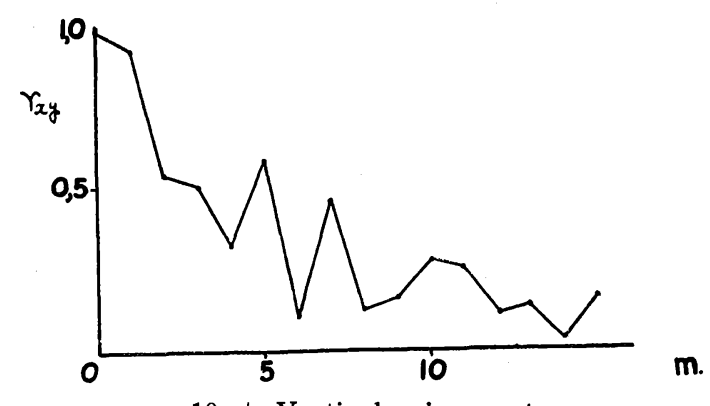

c $10 \mathrm{c} / \mathrm{s}$ Vertical seismometer Fig. 7. Space Correlations Solid line-a (cf. Fig. 8 IV) Broken line-b (cf. Fig. 8 IV) 


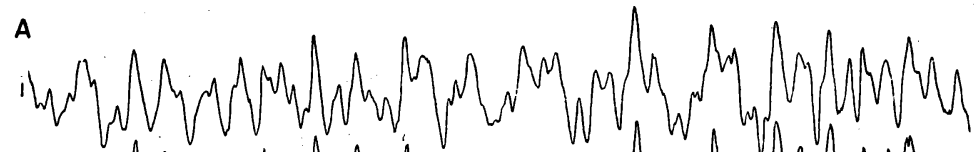

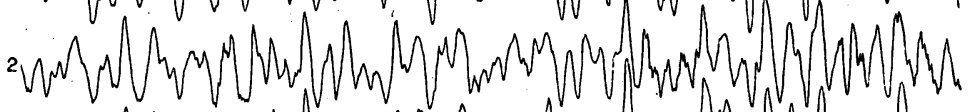

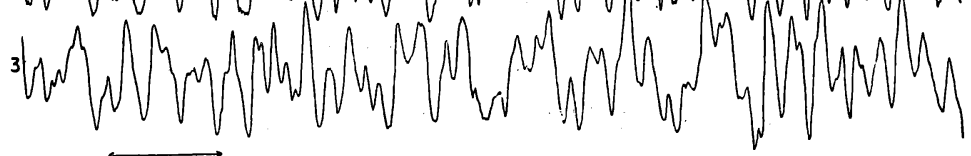

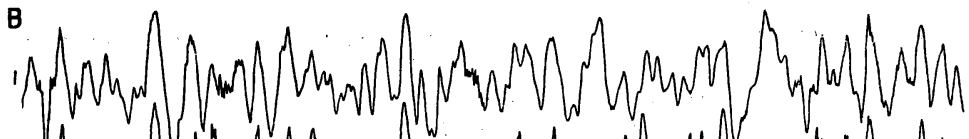

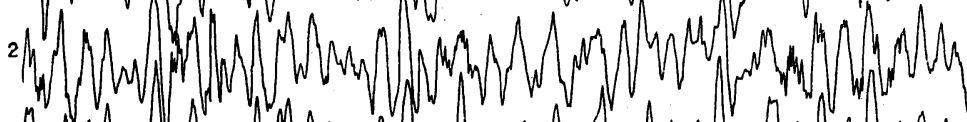

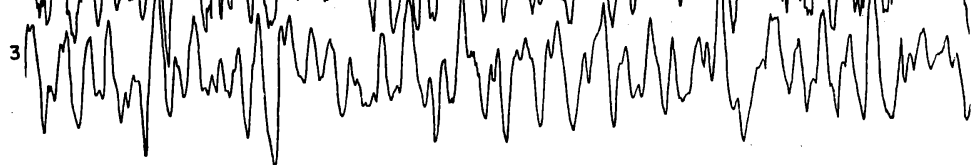

C

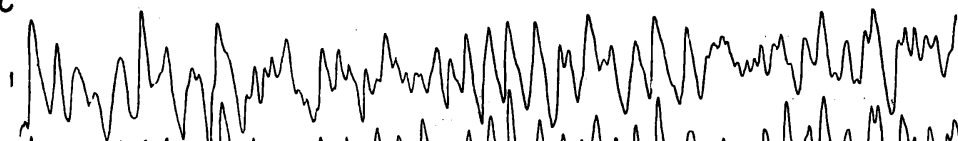

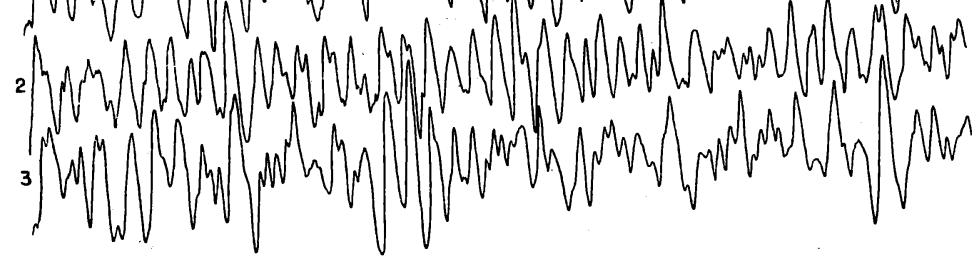

D

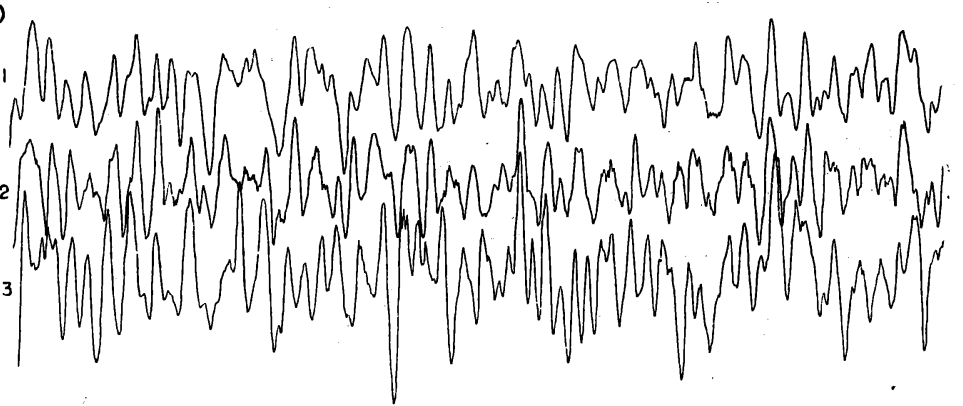

Fig. 8. I Records with $1 \mathrm{c} / \mathrm{s}$ horizontal seismometers.

$$
\begin{aligned}
& \text { A } \quad \mathrm{a}, \mathrm{b}-2 \mathrm{~m} \\
& \text { B } a, b-6 \mathrm{~m} \\
& \text { C } \quad \mathrm{a}, \mathrm{b}-10 \mathrm{~m} \\
& \text { D } \quad \mathrm{a}-12 \mathrm{~m} \quad \mathrm{~b}-18 \mathrm{~m} \\
& \text { a, } \\
& \text {-cf. }
\end{aligned}
$$


A

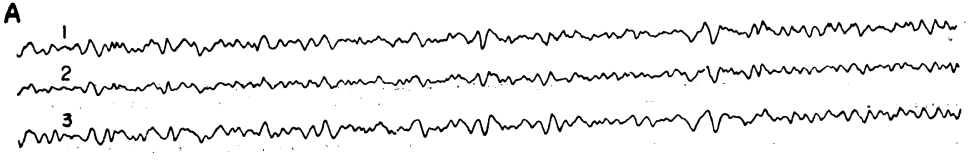
$\stackrel{\text { I sec. }}{\longleftrightarrow}$

B

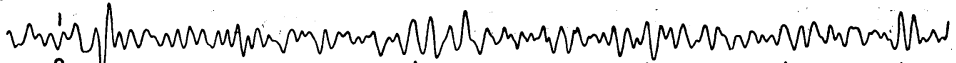

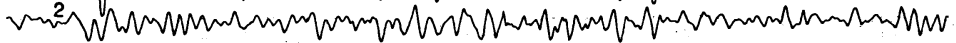

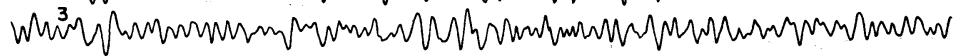

C

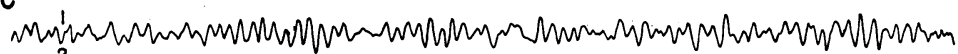

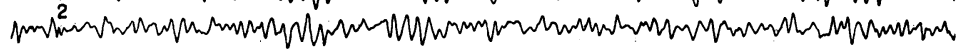

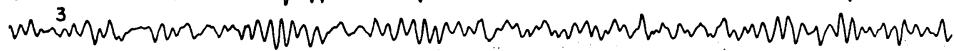

Fig. 8. II Records with $3 \mathrm{c} / \mathrm{s}$ vertical seismometers

$$
\begin{array}{ccc}
\text { A } & \text { a, b } & 2 \mathrm{~m} \\
\text { B } & \text { a, b } & 6 \mathrm{~m} \\
\text { C } & \text { a, b } & 10 \mathrm{~m}
\end{array}
$$

a, b-cf. Fig. $8 \mathrm{IV}$

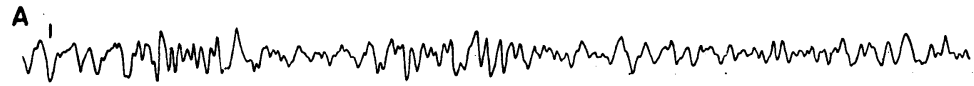

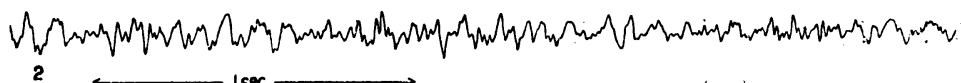

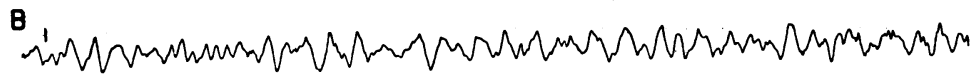

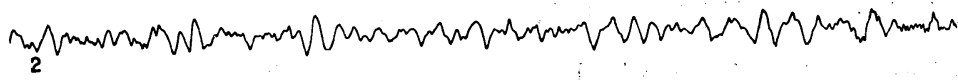

c ,

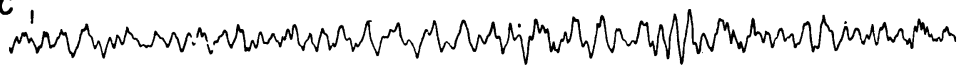

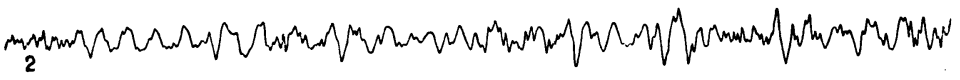

Fig. 8. III Records with $10 \mathrm{c} / \mathrm{s}$ vertical seismometers

$$
\begin{array}{lll}
\text { A } & 1-2 & 2 \mathrm{~m} \\
\mathrm{~B} & 1-2 & 6 \mathrm{~m} \\
\mathrm{C} & 1-2 & 10 \mathrm{~m}
\end{array}
$$

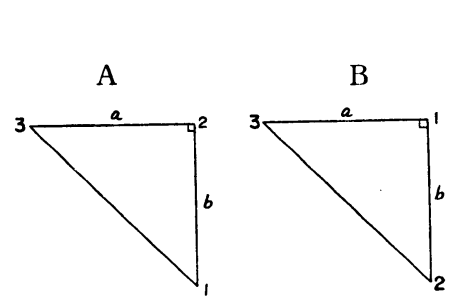

Fig. 8. IV Observation points to record numbers.
A $\quad 1 \mathrm{c} / \mathrm{s}$ Horizontal seismometer.
B $\quad 3 \mathrm{c} / \mathrm{s}$ Vertical seismometer.

\section{A}

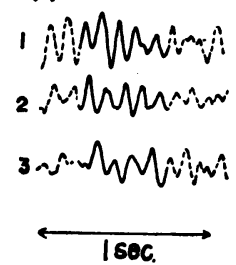

Fig. 9. Records with $3 \mathrm{c} / \mathrm{s}$ vertical seismometers.
A $\quad 1-3 \quad 13 \mathrm{~m}$
B $\quad 1-3 \quad 12 \mathrm{~m}$
1-2 $11 \mathrm{~m}$
1-2 $11 \mathrm{~m}$ 
しく説明する.

次に波の伝播性をしらべるために，2 点の記録について比較的規則的にならんだ波 4〜5山 づつをえらび出し 1/200 秒每に振巾をよみとり， 1/200 秒毎にずらして相互相関の graph を 書いた(Fig. 10)。すなわち $\tau=0$ から最初の山までは 2 点での波の phase のずれをあらわし ている．そこで伝播速度が求められる事になる．この事についても後で述べる事にする.

ii) さて今までは主に相関函数を求める事によつて議論を進めて来たのであるが，次に今ま での記録を直接読みとつてみる事にする。

最初に $3 \mathrm{c} / \mathrm{s}$ 地震計で観測した記録をみると主な波はコレログラムにあらわれる $7 〜 10 \mathrm{c} / \mathrm{s}$ の波から成立つていることがわかる，この 7 ～10 c/s の波の山，谷，山，谷と 3 つづつの山， 谷が続く wave train がくりかえされてコレログラムにあらわれるより長い周期の波を形づく つている.この周期は約 0.3 秒である. 同一時刻に和ける $10 \mathrm{c} / \mathrm{s}$ 以上の短周期の波（概して 小振巾）は観測点が 2〜3 $\mathrm{m}$ はなれると対応がつかなくなる. 比較的長い周期の波，これは $3 \mathrm{c} / \mathrm{s}$ 附近の波であるが overlapping mean 等の方法をとるとよく対応がつき， 2 点の距離が $7 \mathrm{~m}$ はなれた所でも著しくあらわれている.この現象は前述の空間的相関の graph で短周期 の方が距離によつて 急激に減小することと全く同じ意味をもつている.

以上の記録から， 3 点共波形がよく対応のつく部分をえらび出した. この対応のつく部分は せいぜい 3〜5 周期位の比較的振巾の大きい規則的な波である.その周波数はコレログラムに よくあらわれる 7〜 $10 \mathrm{c} / \mathrm{s}$ 附近の波である.この様な波が 3 点共対応がよくつく部分は記録の 上ではごくわずかである.（例えば Fig.9. A, B) 2 点の波形はよく対応がついても 3 点目の波形

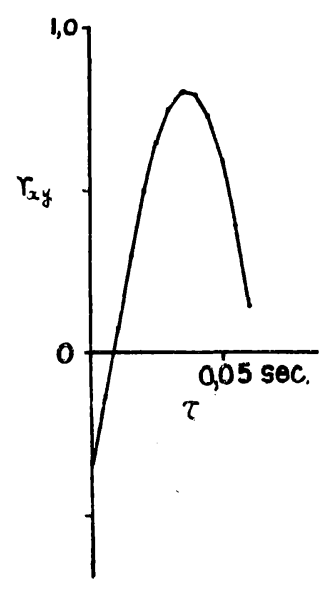

1-3

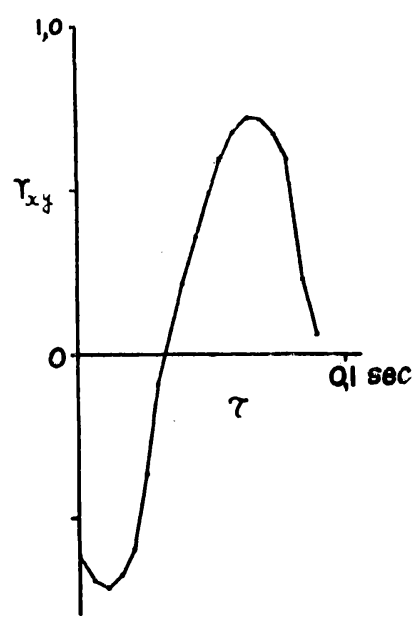

2-3

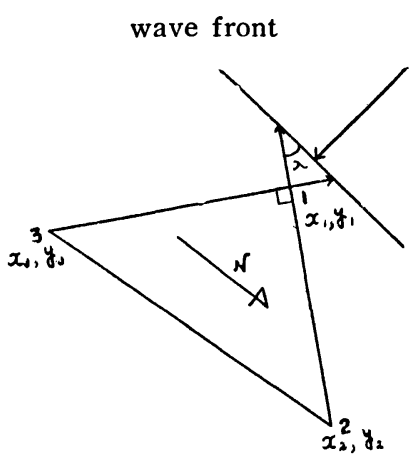

Fig. 11.

Fig. 10. Cross-correlation functions from Fig. 9-A. 
はくずれていて対応がつかない所もある.先に述べた cross correlation によつて各々の 2 点間 に波の到着する時間のずれがわかるから波の伝播する方向及び phase velocity が求められる.

例えば Fig. 11 の様に $x_{1}, y_{1}$ を原点とすれば Fig. 9. A, Fig. 10. 及び Fig. 11 より $x_{2}$ $=0, y_{2}=-11, t_{2}=7 / 200$ (sec.), $x_{3}=-13, y_{3}=0, t_{3}=19 / 200$ (sec.) $(7 / 200+12 / 200)$ であるから これから $\lambda$ 及び $v$ を計算すると $\lambda=24^{\circ} 28^{\prime}, v=125 \mathrm{~m} . / \mathrm{sec}$. となる. 同様にして Fig. 9 B につ いても $\lambda, v$ を計算すると $\lambda=6^{\circ} 13^{\prime}, v=230 \mathrm{~m} . / \mathrm{sec}$. となる.

この様にして求められた伝播速度は 100 300 m./sec. であるから, 表面波的性質をるつるの と考兄れる.島悦三氏の結果 (未発表)によれば実験を行つた場所は厚さ $1 \mathrm{~m}$ の soil の下 に嬮さ $8 \mathrm{~m}$ の loam の層があり, 更にその下は sand の層になつているのであるが loam 層 の縱波の速度は島氏の結果より $330 \mathrm{~m}$. $/ \mathrm{sec}$. soil の速度は $150 \mathrm{~m}$. $/ \mathrm{sec}$. 又砂層では $1200 \mathrm{~m}$. $/ \mathrm{sec}$ と出ているから上の微動の結果は表面波と考えてもよいと思う．速度についてのばらつきは色 々な方向から来た波が合成された結果とも考兄られる。

$1 \mathrm{c} / \mathrm{s}$ の水平動地震計で行つた 3 点観測の記録で著しい事は屋外（土の上）の記録の方が室内 (コンクリート台）にくらべ短周期が多く山がくずれ易い事である.

記録をよくみると 2 点間の距離が $4 \mathrm{~m}$ 位へだたると $10 \mathrm{c} / \mathrm{s}$ 以下の波は殆ど対応がつかな い. $3 \mathrm{c} / \mathrm{s}$ 地震計で記録したものと同様に 2 点の記録をみるとよく対応がつくが，他の 1 点が 対応がつかない場合がある. 又 $5 \mathrm{c} / \mathrm{s}$ 附近の波は $6 \mathrm{~m}$ 迄 3 点共よく似ている. $1 \mathrm{c} / \mathrm{s}$ 位の波 は $18 \mathrm{~m}$ 迄よく対応がついている. $3 \mathrm{c} / \mathrm{s}$ 地震計の記録にみられる様な目立つた wave train はみられないが比較的振巾の大きい 2〜6 山位の規則的な wave train が記録されている.

$10 \mathrm{c} / \mathrm{s}$ 地震計では 2 点の波がよく対応がつくのは $5 \mathrm{~m}$ 迄である. その記録によくあらわれる 波は $10 \mathrm{c} / \mathrm{s}$ 附近の周波数である.

土地の固有振動をあらわす波については，今回の実験でははつきりとわからなかつたが，例 えば $1 \mathrm{c} / \mathrm{s}$ 水半動地震計の記録では 2 点が $18 \mathrm{~m}$ はなれていても長周期の波は対㐫がつくので ある. 相互相関係数も 0.4 位の值を示している. 昼と夜の記録については振巾の減小を別にし て目立つた差はない様である。夜間の観測は今後更に続けるつもりである。これは前に述べた 波の伝播して来る方向と更に 2 点間の距離による相関が猎と夜では周期によつてどの程度異る かという事もくわしく調べたいと思う。

\section{§6. 振巾の分布}

記録上 1/50 秒每に振巾をルーペでよみとつてその frequency distribution curve を書く

(Fig. 8. I 飞牧いて $3 \mathrm{c} / \mathrm{s}$ 上下動地震計と比較して短周期が目立つのは地面に特いた時の風の影響であ ろろか.) 
そ Fig. 12 の様になる. 振巾の分布はコレログラムを作る場合に，実際に振巾をよみとるの
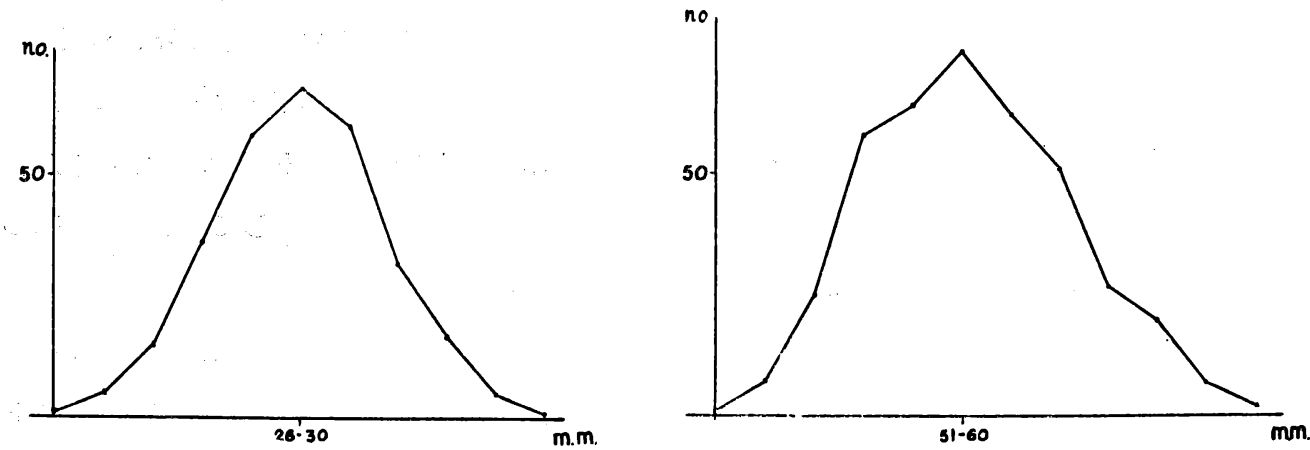

a, 3 c/s Vertical seismometer. (Sample size 300) b, 1 c/s Horizontal seismometer. (Sample size 400) Fig. 12. Frequency Distributions of Amplitudes.

そナ,一でよみとつて計算する時の差に影響するのである.（この場合は大体 gaussian 分布 とみなされる.)

\section{§7. 筑波山と本郷との微動の比較}

筑波山で使用した地震計は $3 \mathrm{c} / \mathrm{s}, 10 \mathrm{c} / \mathrm{s}$ 上下動地震計, $1 \mathrm{c} / \mathrm{s}$ 水平動地震計, 帯域 1 30 $\mathrm{c} / \mathrm{s}$, 及び $30 \sim 300 \mathrm{c} / \mathrm{s}$ の増巾器等である.（増巾器は積分回路なし）観測は比較的おだやかな 日の虽と夜行つた。記録を Fig. 13 に示す.

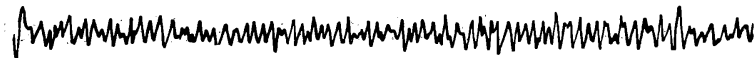

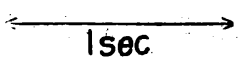

Fig. 13. Records with $3 \mathrm{c} / \mathrm{s}$ vertical seismometer at Tukuba.

筑波山と本郷で記録した微動学比較すると微動の振巾の order は屋外で筑波山は本郷の数 百分の一である，地震計を地震計室の観測用の台（これは岩石の上にすえられてある）に拈い て観測した場合にはその振巾は土の上（測定した場所は上側の恐らく数 10 糎は土壌であろう.)

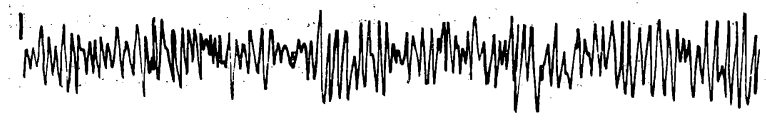

\section{2}

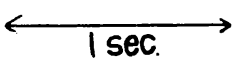

Fig. 14. Records with $3 \mathrm{c} / \mathrm{s}$ vertical seismometers at Tukuba.

1 On the ground.

2 On a concrete block.

に执いた場合の約 $1 / 8$ 位になる.これを Fig. 14 に示す。

筑波での記録では約 $20 \mathrm{c} / \mathrm{s}$ の短周期の微動が著しくみられる. 螱と夜の振巾の比は $2: 1$ で 
ある.筑波での観測の結果によると $10 \mathrm{c} / \mathrm{s}$ 上下動地震計と 短周期増巾器によつて記録される 微動は風雨に対して非常に敏感である. 風雨の激しい時は数 10 サイクルの微動の振巾は 10 倍 以上になる事もある.地震研究所筑波支所の様に静かな場所では人間の足音等が 100 米位へだ つている所でも back ground noise より十分大きく記録される.

\section{§ 8. 結語}

さきに述べた目的により微動を microscopic に調べるために，その日变化を調べ 3 点観測 等を行つて得られた記録を解析した。微動の microscopic な構造を十分明らかにするには不 十分であるが得られた結果は，

1. 振巾の日変化は 7 $10 \mathrm{c} / \mathrm{s}$ の周波数のもので屋と夜の比は $17: 1$ 飞も拈よぶ. 筑波では $20 \mathrm{c} / \mathrm{s}$ の周波数のものが卓越しその日变化は $2: 1$ 位で女る.

2. 色々な response をもつ地震計で微動を観測しスペクトラムを求めた結果，3〜 $4 \mathrm{c} / \mathrm{s}$, $7 \sim 10 \mathrm{c} / \mathrm{s} .8 \sim 10 \mathrm{c} / \mathrm{s}$ 等の周波数のものが本郷の台地では存在する. 筑波では数サイクルから 数 10 サイクルの帯域の内では $20 \mathrm{c} / \mathrm{s}$ の凬波数のものが卓越している.

3. 3 点観測の記録について，波の伝播する方向を調べた結果 $7 〜 10 \mathrm{c} / \mathrm{s}$ の波についてはそ の方向が見出された．更に phase velocity も計算された．その velocity から考えるとそれ 等の wave group は表面波的性質をるつ様である. 又相へだつた 2 点で記録された微動につ いて相関をとつてみると短周期の波程相関が 2 点間の距離と共に早く減小する.

将来色々な場所について, 微動についてまだ知られていない基礎的な事実を明らかにして行 き度いと思う。

終りに, 終始熱心に御指導, 御激励をいただいた松沢教嗳, 浅田助教授に深く感謝する. 御 討議いただいた安芸敬一氏に, 実験に協力していただいた小口雄康氏に感謝する. 又相関器に ついては郵政省電波研究所平尾邦雄氏, 富士通信機製造株式会社池田敏雄氏, 石井康雄氏の拉 世話になつた。諸氏の御愿意に感謝する。

\section{参 考 文 献}

1) M. Ishimoto; Observation sur les Secousses d'une petite Amplitude. B.E.R.I. 15 (1937), 697.

2) K. Kanai, T. Tanaka, \& K. Osada; Measurement of the Micro-tremor I. B. E. R. I. 32 (1954), 199.

3) H. E. Tatel, M. A. Tuve \& P. J. Hart; The Earth's Crust-Seismic Studies-Annual Report of the Director of the Dep. Terr. Mag. 1953 54 p. 51.

4) Y. Tomoda \& K. Aki; Frequency Analysis of Local Tremors of the Ground by means of a Magnetic Microseismic Spectrometer. Zisin Ser. 25 (1952), No. 3 p. 17.

5）友田好交；「級間の数を 2 として簡単飞相関係を求める方法」地震 Ser. 27 (1954), 55.

6) K. Akamatu; Tomoda's Method for Calculating the Correlation Coefficients as Applied to Microtremor Analysis. Joun. Physics of the Earth, 4 (in Press)

7) R. M. Fano; Short-Time Autocorrelation Function and Power Spectra. J. Acous. Soc. Amer. 22 (1950), No. 5 p. 546. 